\title{
Responsibility to Protect: Way to Reduce Oppression or Way to Escalate Oppression
}

\author{
Isuru Liyanage \\ Department of Public and International Law, Faculty of Law, University of Colombo, Colombo, Sri Lanka \\ Email: isurumaduka@gmail.com
}

How to cite this paper: Liyanage, I. (2021). Responsibility to Protect: Way to Reduce Oppression or Way to Escalate Oppression. Beijing Law Review, 12, 1049-1058. https://doi.org/10.4236/blr.2021.124053

Received: September 13, 2021

Accepted: November 6, 2021

Published: November 9, 2021

Copyright $\odot 2021$ by author(s) and Scientific Research Publishing Inc. This work is licensed under the Creative Commons Attribution International License (CC BY 4.0).

http://creativecommons.org/licenses/by/4.0/

\begin{abstract}
Responsibility to Protect (R2P) emerged to reiterate the responsibilities of different stakeholders to eliminate oppressive conditions and uphold international peace and security in the world. Hence, under the notion of R2P, individual states have the responsibility to protect their people, and this responsibility can be extended to the international community as well. Although there is no explicit reference under the Charter of the UN, the international community has taken steps to absorb the notion of R2P into the international legal frameworks. Against this backdrop, the main aim of this research paper is to perceive the historical evolution of the notion of R2P and to see how it has been used by the international community in dealing with different crisis conditions. Thus, this paper will initially deal with the conceptual underpinning of R2P and its historical evolution. Then, this paper will analyze two UN Security Council (UNSC) resolutions (resolution 1973 and resolution 1996) that have been adopted to invoke R2P. Finally, this paper intends to critically analyze the international practices towards the notion of $\mathrm{R} 2 \mathrm{P}$ by reflecting on UNSC resolutions and state practices. This research uses the desk research method, and thus, the analysis will be based on sources, such as UNSC resolutions, the Charter of the United Nations, international legal instruments, and international scholastic literature. Based on this desk research, it is evident that, although the idea of R2P is vital to eliminate mass atrocities and oppressive conditions, still this has been invoked subjectively and contributed to escalating the conditions. Therefore, this paper believes that it would be commendable if international key players pay due attention to the existing international legal frameworks, including the Charter of the UN, before invoking R2P.
\end{abstract}

\section{Keywords}

R2P, Interventions, The UNSC, Resolutions, Atrocities 


\section{Introduction}

Responsibility to Protect (R2P) is a principle that emerged under the international legal system to protect people against grave atrocities. Based on the seriousness of the violations and the response of the state party, interventions may be permitted, and thus this could limit the sovereign independence of another state (Rodley, 2015: p. 777). According to Ronald Paris, every state has a primary responsibility to protect its inhabitants from mass atrocities, yet if a state fails to perform its responsibility, the principle of R2P will apply broadly and find other means and methods to protect people against such atrocities (Paris, 2014: p. 569). Therefore, R2P will impose an international obligation for grave violations such as crimes against humanity, genocide, war crimes and ethnic cleansing (GCRP, 2020).

Although this is an important concept to address grave atrocities, the practices and usage of the R2P have created a debate in the international sphere. At the same time, this concept has encountered practical problems and, it has resulted in creating ambiguities on the value of this concept. Therefore, the primary objective of this paper is to explore the concept of R2P. To this end, this paper will deal with the conceptual underpinning of R2P and its historical evolution. Then this paper will analyze two UNSC resolutions: First, the resolution passed for Libya (Resolution 1973 (2011)) since it marks the very first intervention which has been authorized under the concept of R2P, and then, the resolution passed for South Sudan (Resolution 1996 (2011)). Finally, this paper intends to critically analyze the international practices towards the notion of R2P by reflecting on UNSC resolutions and state practices. To this end, this part will critically analyze the implementation of resolutions 1973 \& 1966 and international responses towards invoking R2P for an unresolved crisis.

\section{Road to R2P}

Although this principle has gained recognition within the UN membership there is no explicit provision in the UN Charter relating to this principle. Therefore, at the outset, it is important to see how far an alien intervention can be legitimate under the existing UN system. Although there are few exceptions, the general principle is no state is permitted to use force against another state (Article 2 para 4 of the UN Charter). According to Rodley (2015: p. 779), this idea has been further reaffirmed by Article 2(7) of the UN Charter since it introduces the principle of non-intervention. Accordingly, if there is a grave violation of the rights of the people, the state must address the matter by relying on the methods and means available within their jurisdiction. These provisions resonate with the Westphalian notion of state sovereignty. Nevertheless, according to scholars, Article 2 (4) of the UN Charter can interpret and understand more broadly to rescue a population from extreme persecution (Rodley, 2015: p. 779). Accordingly, the intervention of this nature would not amount to a limitation of political independence or territorial integrity of the state being intervened (Rodley, 2015: p. 
779). Similarly, Rodley suggests that such interventions will not affect the principle enshrined in Article 2(7) of the UN Charter since humanitarian interventions would not be inconsistent with the underpinning objective of the UN (Rodley, 2015: p. 779). Therefore, such interventions can proceed under the Chapter VII of the UN Charter as well. Yet, this argument/interpretation is still subject to international discourse and can open room for ambiguities and $\mathrm{mi}$ sinterpretations. Further, the concept of R2P has evolved "in response to the failure of the international community to adequately respond to mass atrocities committed in Rwanda and the former Yugoslavia during the 1990s" (GCRP, 2020). The International Committee on Intervention and State Sovereignty was involved significantly in the road to developing the concept of R2P during 2001. And thereafter in 2005, the principle of R2P was unanimously adopted at the UN World Summit (Paris, 2014: p. 569). Recognizing this concept in the 2005 World Summit Outcome Document is cardinal since it marked a milestone in conceptualizing this idea. Later this concept was further expanded and modified with UNSC resolutions and international state practices since 2011.

\section{R2P as a Standalone Principle}

Fundamentally, this idea has been articulated in paragraphs 138 and 139 of the World Summit Outcome Document (WSOD). According to paragraph 138 of the WSOD, "each state has the responsibility to protect its populations from genocide, war crimes, ethnic cleansing and crimes against humanity and international community accepts this responsibility and acts accordingly. Same time the international community shall encourage and assist states to exercise this responsibility". On the other hand, paragraph 139 of the WSOD imposes the responsibility on the international community. Accordingly, the international community must exercise the responsibility through the UN, by using humanitarian, peaceful or other appropriate means to protect people following Chapter VI and VIII of the UN Charter. Additionally, the international community can take collective action through the Security Council under the Chapter VII of the UN Charter on a case by case basis when peaceful means are inadequate or when national authorities fail to protect their population from mass atrocities (WSOD 2005: Para 139). Therefore, these two paragraphs codify the cases where the international community (through the Security Council) uses force to protect people against mass atrocities. And these two provisions introduced the three pillars of R2P, and hence, in the next part, this paper intends to discuss three pillars of the concept of R2P more elaboratively.

\section{Three Pillars of the R2P}

In 2009 UN Secretary-General Ban Ki-moon released a report on "Implementing the R2P". This report affords examples of policies and practices that are contributing to the advancement of goals relating to the responsibility to protect under each of the pillars (UNGA, 2009: p. 2). This report was heavily based on Articles 
138 and 139 of the 2005 World Summit Outcome Document and listed three pillars. Accordingly, first, every state has the Responsibility to Protect its population from four mass atrocity crimes: genocide, war crimes, crimes against humanity and ethnic cleansing (UNGA, 2009: p. 1). Under the second pillar, the wider international community has the responsibility to encourage and assist individual states in meeting that responsibility; (UNGA, 2009: p. 1). Thirdly, if a state is concerned manifestly failing to protect its populations, the international community must be prepared to take appropriate collective action, in a timely and decisive manner and following the UN Charter (UNGA, 2009: p. 1).

Therefore, the responsibility perceived under the first pillar required states to take preventive measures about grave crimes (UNGA, 2009: para 11a). Further, the same report notes that "the responsibility derives both from the nature of State sovereignty and from the pre-existing and continuing legal obligations of States, not just from the relatively recent enunciation and acceptance of the responsibility to protect" (UNGA, 2009: para 11a). The analysis of this principle suggests that the first pillar relies on the principle of non-intervention and thus, highlighted, and respected state capability in handling matters that occur within its own territorial borders.

Then when it comes to the second pillar, the international community and competent interest parties are supposed to extend their peaceful hands to relevant states in addressing their tragedies. This pillar attempts to draw on the "cooperation of Member States, regional and sub regional arrangements, civil society and the private sector, as well as on the institutional strengths and comparative advantages of the United Nations system" (UNGA, 2009: para 11b). Hence it is amply clear that the second pillar relies on peaceful means and methods to address atrocities. Also, this pillar is perceived as the key ingredient for a successful strategy for the notion of R2P (UNGA, 2009: para1b).

However, the third pillar, which imposes a responsibility on the international community, regional organization, or allied stakeholders, goes beyond the degrees of the first and second pillars. This pillar is controversial since it authorizes the international community to intervene in a problem in a sovereign state by employing coercive means. Accordingly, it "permits coercive measures by outsiders, ranging from economic sanctions to direct military actions" (Paris, 2014: p. 572). But in most instances, the actual scope of this is misunderstood or misinterpreted. Because as suggested in the Secretary-General's guidelines, the responses of the international community under the third pillar, should be reasoned, calibrated and, timely and hence, that could involve any of the broad range of tools available to the United Nations and its partners (UNGA, 2009: para 11c). Thus, these measures include pacific measures under Chapter VI of the Charter, coercive ones under Chapter VII and/or collaboration with regional and subregional arrangements under Chapter VIII (UNGA, 2009: para 11c). Against this backdrop, next, this paper will explore the Security Council Resolution numbers 1973 (2011) and 1996 (2011) to examine the practical application 
of R2P.

\section{Use of R2P in Practice}

This paper has selected two UNSC resolutions to analyze the practices of R2P. Namely, Resolution 1973 (adopted in March 2011) for Libya and Resolution 1996 (adopted in July 2011) for South Sudan. Although these two resolutions are not recent, the analysis of the same today is pivotal to explore the understanding and application of the notion of this concept at the initial stages of R2P. Therefore, this part will analyze these two resolutions separately by focusing on the background, use of R2P and its mandate.

\subsection{Resolution 1973}

Scholars identify resolution 1973 as an experiment conducted by the international community to find the practicability of R2P (Paris, 2014: p. 580). The crisis of Libya opened the avenue to pass this resolution. Libyan anti-government demonstrations began in 2011 with the influence of the Arab Awakening originated in Tunisia in late 2010 (Cowell, 2011: p. 14). Then the regime security forces used vibrant military methods to control the situation, which led to killings and atrocities in Libya (Paris, 2014: p. 580). Further, UN officials warned the officials of Libya about the mass atrocities and urged their responsibility to protect people within its territory. Since they failed to uphold their state responsibility effectively, the international community decided to invoke this principle through the Security Council. At the outset, the Security Council adopted Resolution 1970 (2011 February 26) that urged state "responsibility to protect its population" and imposed an arms embargo on the country, among other things. However, Qaddafi's group continued with the mass atrocities despite the warnings and responses of the international and regional organizations (Paris, 2014: p. 581). The constant situation paved the path to the resolution 1973. Resolution 1973 is indeed an immediate action to protect people and as a means of exercising R2P. This resolution has passed under the authority vested to the Security Council by Chapter VII of the UN Charter. This resolution has reiterated the responsibility of the Libyan authorities to protect people from atrocities (UNSC, 2011a: p. 1). And the no-fly zone introduced by the 1973 resolution was a cardinal thing that assisted in protecting the citizens.

Significantly, this resolution has condemned the gross and systematic violation of human rights, including arbitrary detentions, enforced disappearances, torture and summary executions. And this resolution evaluates the systemic and widespread attacks of Libyan Arab Jamahiriya and hence, perceived those as violations of crimes against humanity (UNSC, 2011a: p. 1). Further, this resolution has permitted member states to take all necessary measures to protect civilians from mass atrocities and then, those member states concerned were requested to inform all measures taken by them to the Secretary-General, which is then supposed to bring to the notice of the Security Council immediately(UN SC Res. 
1973:para 4). Accordingly, NATO took the lead in intervening while some European and regional countries expressed their support to it (Paris, 2014: p. 581). This marks the approval to intervene in the situation in Libya based on humanitarian grounds. Additionally, this resolution has imposed a fly zone, assets freeze, enforcement of the arms embargo and ban on flights to intervene and address the crisis in Libya. Further, the analysis of this crisis demonstrates that the three pillars of the R2P are there at different levels. Therefore, as a positive thing, this paper perceives resolution 1973 as a progressive step in realizing this idea. However, still, there are some criticisms about the implementation and outcome of this initiative. Because even after this resolution the UNSC had passed some resolutions in terms of the situation in Libya. The most recent three resolutions are the Resolutions numbers 2016 (in 2011), 2040 (in 2012) and 2095 (in 2013) that passed for Libya. These resolutions “... stresses the Libyan authorities' responsibility for the protection of its population, including foreign nationals and African migrants" (UNSC, 2013: para 5). Further, this paper will discuss the practical issues of resolutions for Libya under the third part of this paper.

\subsection{Resolution 1996}

The UNSC resolution 1996 can be considered as the dominant resolution passed for South Sudan because this was adopted by the Security Council on 8 July 2011, which is soon after its independence process. Most importantly, this resolution welcomed the newly established independent state (UNSC, 2011b: p. 1). The passing of this resolution is quite different from the Libyan Resolution (1973). In this situation, without giving some time for this state to address their domestic issues, UNSC adopted this soon after its establishment. This amply portrays the level of the motivation of the international community to address the crisis of South Sudan. Accordingly, by acting on the authority vested under the Chapter VII of the UN Charter, at the outset, UNSC established the United Nations Mission in the Republic of South Sudan (UNMISS) and further and further decided that UNMISS will consist of up to 7000 military personnel (UNSC, 2011b: para1).

The mandate of UNMISS included activities to consolidate peace and security and to help establish the conditions for development in the Republic of South Sudan and establish good relations with its neighbors' (UNSC, 2011b: para 3). Thus first, UNMISS was supposed to assist the government of South Sudan to protect its people (UNSC, 2011b: para 3b). Then resolution 1966 has authorized UNMISS to employ all necessary means (inter alia) to deter "violence including through proactive deployment and patrols in areas at high risk of conflict and protect civilians under imminent threat of physical violence, in particular when the Government of the Republic of South Sudan is not providing such security" (UNSC, 2011b: para4). Therefore, this has relied on the requirements of unwillingness and inability of the state party concerned when adopting it. Although they are subject to review, UNMISS has given the discretion here to decide what 
is "necessary means" to them when using fore. However, this resolution has failed to recognize the South Sudan government's responsibility to protect explicitly. This can be considered as an omission since the main aim here is to invoke R2P by following the guidelines of the Secretary-General's 2009 report. Therefore, in 2016 March UNSC adopted another resolution (Resolution 2016/1) to cover this. Additionally, there were some practical obstacles in the full implementation of this resolution as it intended. And these challenges and issues will be discussed in the next part of this paper.

\section{R2P Interventions: Good or Bad}

It shows that those states that are economically fragile, poor or who are suffering from severe internal issues are the ones that have been subject to interventions under R2P. This part has two subparts. The first subpart will critically analyze the 1973 and 1996 resolutions. Then the second subpart will focus on the Syrian crisis and analyze how far the international community has been able to invoke $\mathrm{R} 2 \mathrm{P}$ to address the said crisis.

When it comes to the 1973 resolution, NATO took the lead in intervening as noted previously. However, scholars believe that interveners have failed to understand the scope of the Libyan crisis before intervening and, their true underlying primary objective was to defeat and remove Gaddafi. Yet, there was no proper plan to rebuild and uphold good governance in Libya (Aaronson, 2011: p. 1). Although the UNSC was very quick in passing the 1973 resolution, it has not been able to address the oppressive condition of similar states at the same pace. Scholars state that "arguably, Libya was a country about which the interveners knew very little at the start of the intervention and know not much more as it ends" (Aaronson, 2011: p. 1). This shows how far these interveners have prospered during the mission. Further, UN Ambassador Hardeep Singh Puri noted that "the Libyan case has already given R2P a bad name" and he further stated that the "Only aspect of the resolution [that was] of interest to them was the use of all necessary means to bomb the hell out of Libya. In clear violation of the resolution, arms were supplied to civilians without any consideration of its consequences. The No-fly zone was selectively implemented, only for flights in and out of Tripoli. Targeted measures were implemented insofar as they suited the objective of regime change" (Prashad, 2012). Although many parties intervened in the conflict with NATO, coordination between them was not satisfactory. Different interveners had different motives and, it hindered the accomplishments of this mission and led to criticism.

Further, resolution 1996 has some criticisms for the practicability of the core objectives. The UNMISS is the core creation under this resolution and fortunately, the newly appointed government showed their interest in working with the UNMISS (WPC, 2017: p. 2). Yet according to literature, the mandate of the UNMISS was too broad and hence it aimed "to support the newly established government in accomplishing large goals in the areas of development, security, 
institution building, and rule of law" (WPC, 2017: p. 2). Also, compared to resolution 1973, resolution 1996 has merely used the notion of R2P within its parameters. Unfortunately, this resolution has not identified any specific crimes that UNMISS or government needs to deal with, instead, it has used blanket terms such as "protection of civilians from physical violence" (UNSC, 2011b: para 3b). As noted above UNMISS faced significant challenges to its mandate and this was evident from its inception. The December 2011-January 2012 Jonglei crisis and violations of the Status of Forces Agreement are some notable instances and hence, eventually, UNMISS had to prioritize logistical activities over the political portions of its mandate (WPC, 2017: p. 3). Subsequently, UNSC had to adopt resolution 2109 on 11 July 2013 to adjust the original mandate of the UNMISS. However, the mandate of the UNMISS was altered later as well (2014) and it shows how far the 1996 resolution prospered.

Next, this part intends to discuss the crisis in Syria and explore how far the international community/superpowers have been able to invoke R2P in this situation. Although the prolonged crisis in Syria has resulted in severe damage to its people, the international community or the UN Security Council has not taken action to invoke R2P by employing any coercive measures like Libya. The UNSC has passed several resolutions for Syria since 2014. Nevertheless, all have urged the state responsibility of the government and authorities of Syria and has not gone beyond. Unlike the Libyan situation, UNSC has not acted at the same pace to employ the most needed actions to protect these people. This paper believes that international geopolitics and the interests of superpowers have influenced this, and thus, it shows how the R2P can be used subjectively for hidden purposes by limiting the state sovereignty of fragile countries. On the other hand, during the Trump administration, the US attacked Syria over certain chemical weapons. However, the aim of this attack was not to end the conflict in Syria (Crowley \& Restuccia, 2018). The objective of this strike was to protect the USA by deterring chemical weapons in Syria (Crowley \& Restuccia, 2018). This act does not belong to the notion of R2P yet an act of an individual state. Although the Charter of the UN has permitted states to use force against another country in exceptional situations, still state parties are not authorized to act arbitrarily and with no proper evidence. Except in all other situations parties are mandated to uphold the principles of the UN. This clearly shows how superpowers tend to intervene in domestic affairs without fulfilling the prerequisites of R2P.

\section{Conclusion}

Hence, indeed the principle of R2P is a pivotal instrument and a mechanism in protecting populations from mass atrocities. When the primary responsible party fails to protect its population, this mechanism opens the doors to the international community to intervene in the situation. In these instances, the objective of such international intervention should be to control the crisis and eliminate 
mass atrocities. However, the success of the R2P will depend on three things: First, the mandate of the interveners; second, the level of cooperation with allied parties and thirdly, bonafide actions towards achieving the mandate. On the other hand, although R2P is significant in addressing oppressing humanitarian problems in fragile states in most cases, it has been invoked by superpowers subjectively. This matter depicts within the above case examples. As a result, the international community has failed to see the spirit, value, and outcomes of the R2P contemporarily. And in most instances, such improper interventions have contributed to escalating the existing conditions by bypassing state sovereignty. Hence, it is amply pivotal to understand the context and purpose before invoking the R2P to promote a sense of sustainable peace.

\section{Acknowledgements}

I would like to express my sincere and deep gratitude to Judge Sergio Ugalde (Judge at the International Criminal Court and Visiting Professor, Department of International Law, University for Peace, Costa Rica) and Professor Kenji Isezaki (Professor, Tokyo University of Foreign Studies, Japan and Visiting Professor, Ateneo de Manila University, Philippines) for providing the theoretical base for this study area.

\section{Conflicts of Interest}

The author declares no conflicts of interest regarding the publication of this paper.

\section{References}

Aaronson, M. (2011). Was the International Intervention in Libya a Success? E-International Relations. https://www.e-ir.info/2011/10/31/was-the-international-intervention-in-libya-a-success

Cowell, A. (2011, February 16). Protests Take Aim at Leader of Libya. New York Times.

Crowley, M., \& Restuccia, A. (2018). Trump Strikes Syria. https://www.politico.com/story/2018/04/13/trump-syria-strikes-523051

Global Center for the Responsibility to Protect [GCRP] (2020). What Is R2P? https://www.globalr2p.org/what-is-r2p

Paris, R. (2014). 'The Responsibility to Protect' and the Structural Problems of Preventive Humanitarian Intervention. International Peacekeeping, 21, 569-603. https://doi.org/10.1080/13533312.2014.963322

Prashad, V. (2012). Syria, Libya, and Security Council. Frontline. https://frontline.thehindu.com/world-affairs/article30164765.ece

Rodley, N. (2015). Humanitarian Intervention. In Oxford Handbook of the Use of Force in International Law (pp. 777-779). Oxford University Press. https://doi.org/10.1093/law/9780199673049.003.0036

UNGA (2009). Implementing the Responsibility to Protect Report of the Secretary-General. A/63/677. https://www.un.org/ruleoflaw/files/SG_reportA 63677 en.pdf

UNSC (2011a). Resolution 1973. https://www.un.org/securitycouncil/s/res/1973-(2011)

UNSC (2011b). Resolution 1996. https://www.refworld.org/docid/4f1d3b322.html 
UNSC (2013). Resolution 2095. https://www.undocs.org/S/RES/2095\%20(2013)

World Peace Foundation [WPC] (2017). African Politics, African Peace. https://sites.tufts.edu/wpf/files/2017/07/South-Sudan-brief.pdf 